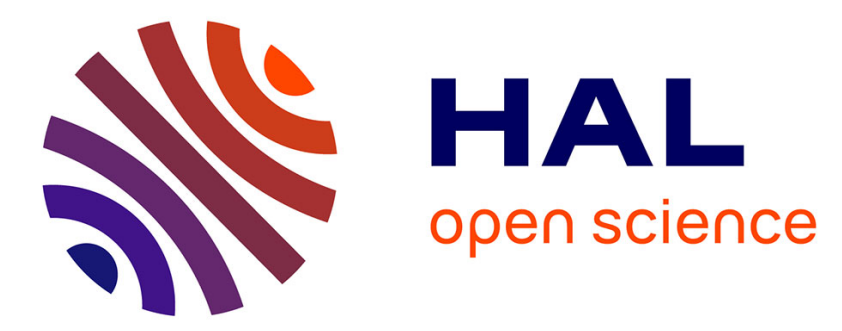

\title{
Preparation and structural characterization of $[\mathrm{CpRu}(1,10-$ phenanthroline $)(\mathrm{CH} 3 \mathrm{CN})][\mathrm{X}]$ and precursor complexes (X= PF6, BArF, TRISPHAT-N)
}

Thierry Achard, Léo Egger, Cecilia Tortoreto, Laure Guénée, Jérôme Lacour

\section{To cite this version:}

Thierry Achard, Léo Egger, Cecilia Tortoreto, Laure Guénée, Jérôme Lacour. Preparation and structural characterization of $[\mathrm{CpRu}(1,10$-phenanthroline $)(\mathrm{CH} 3 \mathrm{CN})][\mathrm{X}]$ and precursor complexes (X= PF6, BArF, TRISPHAT-N). Helvetica Chimica Acta, 2020, 103 (12), pp.e2000190. 10.1002/hlca.202000190 . hal-03455618

\section{HAL Id: hal-03455618 \\ https://hal.science/hal-03455618}

Submitted on 29 Nov 2021

HAL is a multi-disciplinary open access archive for the deposit and dissemination of scientific research documents, whether they are published or not. The documents may come from teaching and research institutions in France or abroad, or from public or private research centers.
L'archive ouverte pluridisciplinaire HAL, est destinée au dépôt et à la diffusion de documents scientifiques de niveau recherche, publiés ou non, émanant des établissements d'enseignement et de recherche français ou étrangers, des laboratoires publics ou privés. 


\title{
Preparation and structural characterization of $[\mathrm{CpRu}(1,10-$ phenanthroline $\left.)\left(\mathrm{CH}_{3} \mathrm{CN}\right)\right][\mathrm{X}]$ and precursor complexes $\left(\mathrm{X}=\mathrm{PF}_{6}, \mathrm{BAr}_{\mathrm{F}}\right.$, TRISPHAT-N)
}

\author{
Thierry Achard, ${ }^{\mathrm{a}}$ Léo Egger, ${ }^{\mathrm{a}}$ Cecilia Tortoreto, ${ }^{\mathrm{a}}$ Laure Guénée, ${ }^{\mathrm{b}}$ Jérôme Lacour *,a \\ a Département de Chimie Organique, Université de Genève, quai Ernest Ansermet 30, 1211 Geneva 4 (Switzerland), \\ jerome.lacour@unige.ch \\ ${ }^{\text {b }}$ Laboratoire de Cristallographie, Université de Genève, quai Ernest Ansermet 24, 1211 Geneva 4 (Switzerland)
}

Dedicated to Antonio Togni

\begin{abstract}
Cationic $\left[\mathrm{Ru}\left(\eta^{5}-\mathrm{C}_{5} \mathrm{H}_{5}\right)\left(\mathrm{CH}_{3} \mathrm{CN}\right)_{3}\right]^{+}$complex, tris(acetonitrile)(cyclopentadienyl)ruthenium(II), gives rise to a very rich organometallic chemistry. Combined with diimine ligands, and 1,10-phenanthroline in particular, this system efficiently catalyzes diazo decomposition processes to generate metal-carbenes which undergo a series of original transformations in the presence of Lewis basic substrates. Herein, syntheses and characterizations of $[\mathrm{CpRu}(\mathrm{Phen})(\mathrm{L})]$ complexes with (large) lipophilic non-coordinating $\left(\mathrm{PF}_{6}{ }^{-}\right.$and $\left.\mathrm{BAr}_{\mathrm{F}}{ }^{-}\right)$and coordinating N-TRISPHAT ${ }^{-}$anions are reported. Complex $\left[\mathrm{CpRu}\left(\eta^{6}\right.\right.$-naphthalene)][BAr$\left.{ }_{\mathrm{F}}\right][\mathbf{1}]\left[\mathbf{B A r}_{\mathrm{F}}\right]$ is readily accessible, in high yield, by direct

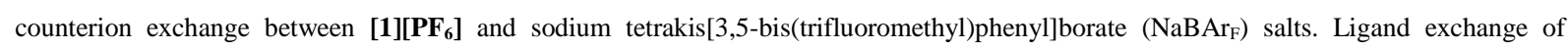

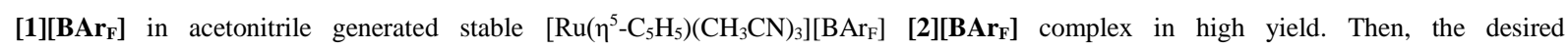
$\left[\mathrm{CpRu}(\mathrm{Phen})\left(\mathrm{CH}_{3} \mathrm{CN}\right)\right][3]$ complexes were obtained from either the [1] or [2] complex in the presence of the 1,10-phenanthroline as ligand. For characterization and comparison purposes, the anionic hemilabile ligand TRISPHAT-N (TTN) was introduced on the ruthenium center, from the complex [3][ $\left.\mathbf{P F}_{6}\right]$, to quantitatively generate the desired complex $[\mathrm{CpRu}(\mathrm{Phen})(\mathrm{TTN})]$ [4] by displacement of the remaining acetonitrile ligand and of the $\mathrm{PF}_{6}{ }^{-}$anion. Solid state structures of complexes [1][BAr $\left.\mathbf{F}_{\mathrm{F}}\right],[2]\left[\mathbf{B A r} \mathbf{r}_{\mathrm{F}}\right],[3]\left[\mathbf{B A} \mathbf{r}_{\mathrm{F}}\right],[3]\left[\mathbf{P F}_{6}\right]$ and $[\mathbf{4}]$ were determined by X-ray diffraction studies and are discussed herein.
\end{abstract}

Keywords: Ruthenium $\bullet$ Cyclopentadienyl $\bullet$ Catalysis $・$ Solid-state

\section{Introduction}

Since its discovery by Gill and Mann in 1982, the cationic $\left[\left(\eta^{5}-\mathrm{C}_{5} \mathrm{H}_{5}\right) \mathrm{Ru}\left(\mathrm{CH}_{3} \mathrm{CN}\right)_{3}\right]$ complex, commonly written $\left[\mathrm{CpRu}\left(\mathrm{CH}_{3} \mathrm{CN}\right)_{3}\right]^{+}$, has proven to be a powerful building block in organometallic chemistry. ${ }^{[1-7]} \mathrm{In}$ fact, the $\mathrm{CpRu}$ fragment, and its $\mathrm{Cp} * \mathrm{Ru}$ analogue, are recognized as effective catalysts for the promotion of many versatile synthetic transformations..$^{[4,5,8-12]}$ Of importance for the current study, combinations of $[\mathrm{CpRu}]$ and nitrogen-based ligands ${ }^{[1,3,13,14]}$ such as diimines ${ }^{[15-26]}$ were also found to catalyze original processes. ${ }^{[7,27,28]}$ For example, $\left[\mathrm{CpRu}\left(\mathrm{CH}_{3} \mathrm{CN}\right)_{3}\right]\left[\mathrm{PF}_{6}\right]$ and pyridine-imine/pyridine-oxazoline ligands are effective catalysts in enantioselective decarboxylative rearrangements of allylic $\beta$-ketoesters and carbonates. ${ }^{[26]}{ }^{[29-32]}$ Kitamura successfully applied enantiopure dipyrroloimidazole ligands and $[\mathrm{CpRu}]$ in enantioselective dehydrative $\mathrm{C}$-, $\mathrm{N}$-, and O-allylation. ${ }^{[14,33,34]} \mathrm{CpRu}$ (bipyridine) complexes were shown to be active catalysts for both deoxygenation of 1,2-hexanediol and glycerol ${ }^{[35]}$ and hydrogenation of ketone in acidic conditions. ${ }^{[36]}$ Previously, Herzon et al. described the efficient anti-Markovnikov hydration of alkynes catalyze by $\left[\mathrm{CpRu}\left(\mathrm{N}^{\wedge} \mathrm{N}\right)\right]\left(\mathrm{N}^{\wedge} \mathrm{N}=\right.$ diimine ligand) derivatives. ${ }^{[37-39]}$

Of interest in our laboratory, the $[\mathrm{CpRu}]$ fragment is also an interesting alternative to transition metal salts and complexes for the decomposition of diazo derivatives providing metal carbene or carbenoid intermediates upon dinitrogen extrusion. ${ }^{[40-45]}$ In fact, in the presence of combinations of $\left[\mathrm{CpRu}\left(\mathrm{CH}_{3} \mathrm{CN}\right)_{3}\right]\left[\mathrm{PF}_{6}\right]$ (as pre-catalysts) and diimine ligands (Phen = 1,10-phenanthroline, in particular), ${ }^{[8,46,47]}$ $\alpha$-diazo- $\beta$-ketoesters react smoothly and provide selective $1,3-\mathrm{C}-\mathrm{H}$ insertions into $\mathrm{THF}^{[48]}$ and $\mathrm{O}-\mathrm{H}$ insertions into alcohols. This catalytic system also promotes condensation reactions with nitriles, ketones, aldehydes and more recently with lactones and cyclic carbonates to generate the corresponding heterocycles (Scheme 1) ${ }^{[49,50]}$ Finally, in recent studies, regio and syn-stereoselective three-atoms insertions into a large variety of epoxides and oxetanes were described leading to the formation of original 1,4-dioxene and 1,4-dioxepine motifs


view of the influence played by the $\mathrm{BAr}_{\mathrm{F}}$ or $\mathrm{PF}_{6}$ anion nature onto the $\left[\mathrm{CpRu}\right.$ reactivity ${ }^{[4]}$ but also, more generally, of the importance of negative counterions in catalysis, ${ }^{[53-55]}$ care was then taken to determine the structural impact associated such gegenions onto $[\mathrm{CpRu}(1,10-$ phenanthroline) $\left.\left(\mathrm{CH}_{3} \mathrm{CN}\right)\right][\mathrm{X}]$ and precursor complexes. 




Scheme 1. One-pot reactions of $\alpha$-diazoacetoacetates and Lewis bases catalyzed by $[\mathrm{CpRu}][\mathrm{X}]$ which stands for $\left[\mathrm{CpRu}\left(\mathrm{Phen}_{)} \mathrm{CH}_{3} \mathrm{CN}\right][\mathrm{X}]\right.$ complexes $(\mathrm{X}=\mathrm{PF} 6$ (blue), $\left.\mathrm{BAr}_{\mathrm{F}}(\mathrm{red})\right)$.

\section{Results and Discussion}

Cationic $\left[\mathrm{CpRu}\left(\eta^{6} \text {-naphthalene }\right)\right]^{+}[1]$ (naphthalene $\left.=\mathrm{Naph}\right)$, a practical and general precursor popularized by E. Peter Kundig for the formation of complex $\left[\mathrm{CpRu}\left(\mathrm{CH}_{3} \mathrm{CN}\right)_{3}\right]^{+}$[2], is readily accessible with an array of negative counterions, such as $\mathrm{Cl}^{-}, \mathrm{CF}_{3} \mathrm{SO}_{3}{ }^{-}, \mathrm{SbF}_{6}^{-}, \mathrm{PF}_{6}^{-}$or $\mathrm{BF}_{4}{ }^{-\left[{ }^{[56]}\right.}$ However and unfortunately, previous attempts to perform anion metathesis of chloride to $\mathrm{BAr}_{\mathrm{F}}$ by a direct exchange of $\left[\mathrm{CpRu}\left(\eta^{6}-\right.\right.$ naphthalene)][Cl] with $\mathrm{NaBAr}_{F}$, were not met with success. ${ }^{[56]}$ This problem could be circumvented in our hands starting from the $\left[\mathrm{CpRu}\left(\eta^{6}\right.\right.$ naphthalene)][$\left[\mathrm{PF}_{6}\right]$ salt instead which was prepared following microwave assisted protocols. ${ }^{[56,57]}$ In practice, a simple mixing for 30 min of $\mathrm{NaBAr}_{\mathrm{F}}$ and $[\mathbf{1}]\left[\mathbf{P F}_{6}\right]$ in a homogenous dichloromethane/acetone solution (1.2/1) provided, after crystallization from dichloromethane and hexane at $4{ }^{\circ} \mathrm{C}$, the desired $\left[\mathrm{CpRu}\left(\eta^{6}\right.\right.$-naphthalene) $]\left[\mathrm{BAr}_{\mathrm{F}}\right]$ complex namely $[\mathbf{1}]\left[\mathbf{B A r}_{\mathrm{F}}\right]$ in good yield $(72 \%$, Scheme 2$)$. The obtained yellow crystals were furthermore suitable for X-ray diffraction analysis, selected bond lengths and angles are given in Table $\mathbf{1}$.
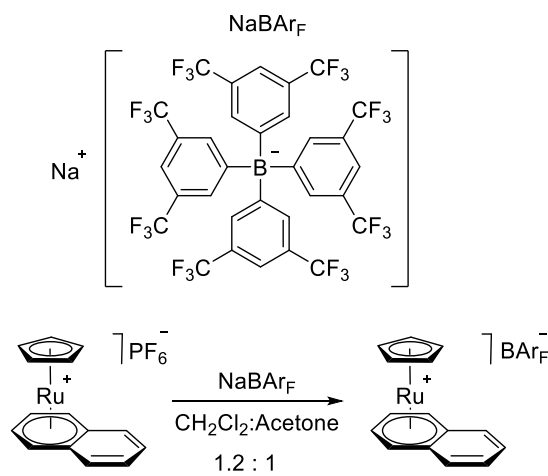

$72 \%$

$[1]\left[\mathrm{PF}_{6}\right]$

[1][BAr ${ }_{\mathrm{F}}$ ]




Scheme 2. Anion metathesis from $\mathrm{PF}_{6}^{-}$to $\mathrm{BAr}_{\mathrm{F}}^{-}$; X-ray structure of [1][BAr $\left.\mathbf{B r}_{\mathrm{F}}\right]$. Thermal ellipsoids are drawn at $50 \%$ probability level and hydrogen atoms omitted for clarity.

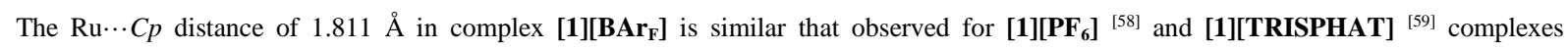
(TRISPHAT $=$ Tris(tetrachlorobenzenediolato)phosphate) but significantly shorter than the corresponding distance in $[\mathrm{CpRu}(\mathrm{benzene})]\left[\mathrm{PF}_{6}\right]$ derivative $(1.845 \AA)^{[60,61]}$ However, the Ru $\cdots$ Naph distances $1.719,1.717$ and 1.725 for [1][PF $\left.{ }_{6}\right],[1]\left[\mathbf{B A r}_{\mathbf{F}}\right]$ and [1][TRISPHAT] respectively, are longer than that reported for the benzene complex highlighting the known higher lability of naphthalene. ${ }^{[6]}$ As observed for other $[\mathbf{1}][\mathbf{X}]$ complexes, the bond lengths of the two quaternary carbons of the bicyclic ring were longer $(0.05 \AA)$ than other Ru-C $\mathrm{C}_{\mathrm{Naphthalene}}$ bonds. ${ }^{[58],[59]}$ The Ru- $\mathrm{C}_{\mathrm{Cp}}$ (average 2.166 $\AA$ ) in [1][BAr $\left.\mathbf{r}_{\mathrm{F}}\right]$ is shorter than others reported for [CpRu( $\eta^{6}$-naphthalene)] complexes. ${ }^{[58],[59]}$

With precursors $\left[\mathrm{CpRu}\left(\eta^{6}\right.\right.$-naphthalene) $][\mathrm{X}]$ in hand $\left(\mathrm{X}=\mathrm{PF}_{6}, \mathrm{BAr} F\right),{ }^{[1-3,56,62]}$ targeted derivatives were readily prepared, thanks to the facile haptotropic $\eta^{6} \rightarrow \eta^{4}$ ring slippage of complexes [1] which allowed the straightforward displacement of the naphthalene ligand by acetonitrile molecules (Scheme 3). ${ }^{[5]}$ At the end of the reaction, the free naphthalene moiety was simply removed by extraction of the acetonitrile solution with dry hexane to afford, after evaporation of the acetonitrile, yellow complexes [2][ $\left.\mathbf{P F}_{\mathbf{6}}\right]$ and $[\mathbf{2}]\left[\mathbf{B A r}_{\mathbf{F}}\right]$ in quantitative yield. ${ }^{[63]}$ Slow diffusion of hexane in a solution of [2][BAr $\left.\mathbf{r}_{\mathrm{F}}\right]$ in methylene chloride at $4{ }^{\circ} \mathrm{C}$ for 3 days yielded suitable crystals for X-ray diffraction analysis (Scheme 3). The Ru‥Cp distance of $1.779 \AA$ in complex [2][BArF] is found slightly shorter compared to [1][BArF]. The three Ru-acetonitrile (AN) bonds are not completely equivalent but their bond distances are in the same range around 2.08-2.09 $\AA$. These differences in the solid state can be explained by the spatial proximity of the acetonitrile moieties to the $\mathrm{BAr}_{\mathrm{F}}$ anion(s) in the crystal unit cell. It was found that the presence of $\mathrm{BAr}_{\mathrm{F}}^{-}$as counterion strongly reduces the oxygen and moisture sensitivity of the $\left[\mathrm{CpRu}\left(\mathrm{CH}_{3} \mathrm{CN}\right)_{3}\right]^{+}$ fragment compared to its $\mathrm{PF}_{6}^{-}$analogue which decomposes under air after a few days only. In addition, the acetonitrile moieties are labile in their own right and this behavior has been strongly exploited to prepare further $[\mathrm{CpRu}]$ derivatives under mild conditions. ${ }^{[1-3,64-77]}$



Scheme 3. Synthesis of $\left[\mathrm{CpRu}\left(\mathrm{CH}_{3} \mathrm{CN}\right)_{3}\right][\mathrm{X}]$; X-ray structure of $[2]\left[\mathbf{B A r}_{\mathrm{F}}\right]$. Thermal ellipsoids are drawn at $50 \%$ probability level and hydrogen atoms omitted for clarity.

In our case, care was taken to utilize 1,10-phenanthroline (Phen) as a model diimine ligand, and the resulting complexes [3][X] were generated either directly from $\left[\mathrm{CpRu}\left(\eta^{6}\right.\right.$-naphthalene $\left.)\right][\mathrm{X}]$ or via the intermediacy of $\left[\mathrm{CpRu}\left(\mathrm{CH}_{3} \mathrm{CN}\right)_{3}\right][\mathrm{X}]$ in acetonitrile solutions. Experimentally, 1 equiv of 1,10-phenanthroline was added to a dichloromethane solution of the desired [2] complex and the resulting purple mixture was stirred at room temperature under argon. Reaction completion was achieved within 2-4 hours affording the corresponding [3][X] moiety (Scheme 4, path a). ${ }^{[78]}$ Practically, these ligand exchange steps can be combined into a single sequential process using acetonitrile as the single solvent. However, in this case, the coordination of 1,10-phenanthroline to the ruthenium center is slower due to the direct competition with coordinating acetonitrile solvent molecules (Scheme 4, paths b and c). ${ }^{[79]}$ In each case, the dark purple solution was evaporated to dryness and the crude mixture was allowed to recrystallize in dichloromethane/hexane to afford complex [3][PF 6 in a high yield of $92 \%$. Dark red X-ray quality crystals were further obtained by slow diffusion of hexane in a THF solution of $[3]\left[\mathbf{P F}_{6}\right]$ at $4{ }^{\circ} \mathrm{C}$ for 3 days and a structural analysis was performed (Scheme 4). Selected bond lengths and angles are given in Table 1. Complex [3][BAr $\left.\mathbf{F}_{\mathrm{F}}\right]$ was synthesized using the same ligand exchange procedure giving after recrystallization, in a 1:3 mixture of hexane:dichlorometane, dark red crystals in 98\% yield. Selected bond lengths and angles are given in Table $\mathbf{1}$ as well. 

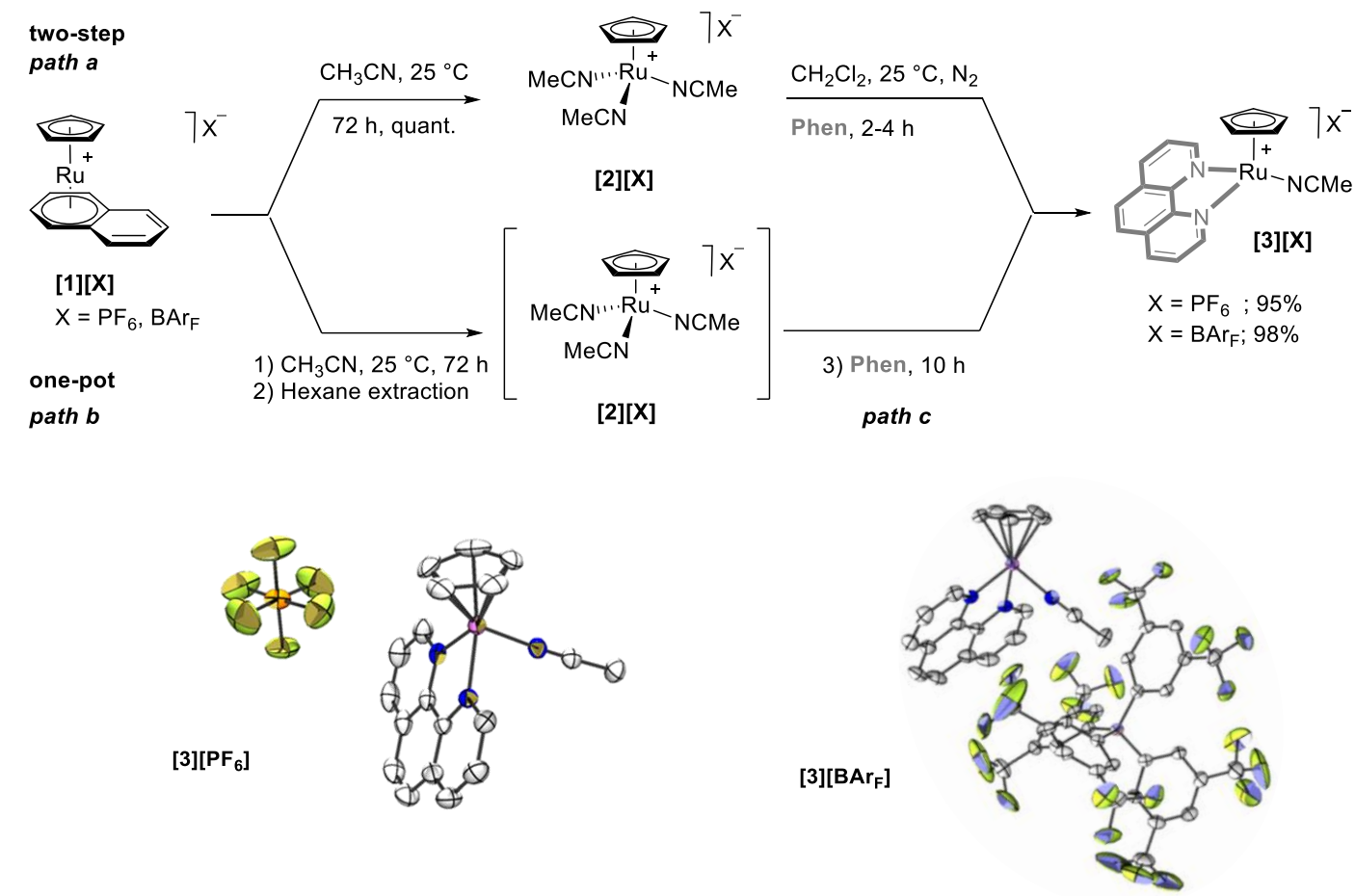

Scheme 4. Synthesis of $\left[\mathrm{CpRu}\left(\mathrm{CH}_{3} \mathrm{CN}\right)_{3}\right][\mathrm{X}]$ and $\left[\mathrm{CpRu}(1,10-\right.$ Phenanthroline $\left.)\left(\mathrm{CH}_{3} \mathrm{CN}\right)_{3}\right][\mathrm{X}]$ complexes $\left(\mathrm{X}=\mathrm{PF}_{6}, \mathrm{BAr}\right)$, salts $[2][\mathrm{X}]$ and $[3][\mathrm{X}]$ respectively.

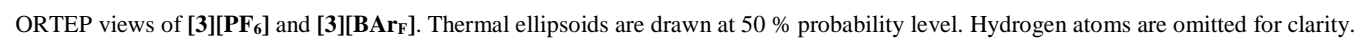

Table 1. Selected bond lengths ( $\AA$ ) and angles (deg) for CpRu complexes 1 to $\mathbf{4}$ with estimated standard deviations in parentheses. ${ }^{[a]}$

\begin{tabular}{|c|c|c|c|c|c|}
\hline Bond lengths /angles & {$[1]\left[\mathbf{B A} \mathbf{r}_{\mathrm{F}}\right]$} & {$[2]\left[\mathbf{B A} \mathbf{r}_{F}\right]$} & {$[3]\left[\mathrm{PF}_{6}\right]$} & {$[3]\left[\mathbf{B A} \mathbf{r}_{F}\right]$} & [4] \\
\hline Ru-N1 $1_{\text {Phen }}$ & - & - & $2.105(3)$ & $2.104(3)$ & $2.109(4)$ \\
\hline $\mathrm{Ru}-\mathrm{N} 2_{\text {Phen }}$ & - & - & $2.106(3)$ & $2.101(3)$ & $2.088(4)$ \\
\hline $\mathrm{Ru}-\mathrm{N} 3_{\mathrm{AN}}$ & - & $2.081 ; 2.089 ; 2.090(3)$ & $2.074(3)$ & 2.074(3) & - \\
\hline $\mathrm{Ru}-\mathrm{N}_{\text {TTN }}$ & - & - & - & - & $2.150(4)$ \\
\hline Ru-P & - & - & $6.281(1)$ & - & $4.872(1)$ \\
\hline $\mathrm{Ru}-\mathrm{B}$ & $8.324(4)$ & $9.721(3)$ & - & $7.890(4)$ & - \\
\hline $\mathrm{Ru}-\mathrm{C}_{\mathrm{Cp}}$ & $2.151(6)$ & $2.138(4)$ & $2.152(4)$ & $2.163(4)$ & $2.175(4)$ \\
\hline $\mathrm{Ru}-\mathrm{C}_{\mathrm{Cp}}$ & $2.158(6)$ & $2.143(4)$ & $2.137(4)$ & $2.146(4)$ & $2.155(5)$ \\
\hline $\mathrm{Ru}-\mathrm{C}_{\mathrm{Cp}}$ & $2.167(5)$ & $2.151(4)$ & $2.151(4)$ & $2.141(4)$ & $2.160(5)$ \\
\hline $\mathrm{Ru}-\mathrm{C}_{\mathrm{Cp}}$ & $2.178(6)$ & $2.152(4)$ & $2.156(4)$ & $2.152(4)$ & $2.144(4)$ \\
\hline $\mathrm{Ru}-\mathrm{C}_{\mathrm{Cp}}$ & $2.182(5)$ & $2.152(4)$ & $2.178(4)$ & $2.154(4)$ & $2.133(5)$ \\
\hline $\mathrm{Ru}-\mathrm{C}_{\mathrm{Naph}}$ & $2.198(5)$ & - & - & - & - \\
\hline $\mathrm{Ru}-\mathrm{C}_{\mathrm{Naph}}$ & $2.202(5)$ & - & - & - & - \\
\hline $\mathrm{Ru}-\mathrm{C}_{\mathrm{Naph}}$ & $2.208(5)$ & - & - & - & - \\
\hline $\mathrm{Ru}-\mathrm{C}_{\mathrm{Naph}}$ & $2.213(5)$ & - & - & - & - \\
\hline $\mathrm{Ru}-\mathrm{C}_{\mathrm{Naph}}$ & $2.261(4)$ & - & - & - & - \\
\hline $\mathrm{Ru}-\mathrm{C}_{\mathrm{Naph}}$ & $2.267(4)$ & - & - & - & - \\
\hline N1-Ru-N2 & - & - & $77.2(1)$ & $77.4(1)$ & $77.9(2)$ \\
\hline N2-Ru-N3 & - & - & $85.9(1)$ & $87.2(1)$ & $85.8(1)$ \\
\hline
\end{tabular}

${ }^{\text {a] }} \mathrm{AN}=$ acetonitrile, $\mathrm{Cp}=$ cyclopentadiene; $\mathrm{Naph}=$ naphthalene, $\mathrm{TTN}=$ Trisphat-N 
Previously, our group reported the synthesis and the resolution of hexacoordinated phosphorus(V) TRISPHAT-N anion (TRISPHAT-N = Bis[3,4,5,6-tetrachlorobenzene-1,2-diolato][5-chloropyridine-2,3-diolato]phosphate). ${ }^{[80]}$ This chiral anion, owing to the presence of a Lewis basic pyridine moiety in the framework, has the ability to coordinate to metal centers; previous studies demonstrating an allied hemilability. ${ }^{[80,81]}$ Furthermore, an important lipophilicity is given by the phosphate skeleton which then allows the ready chromatographic

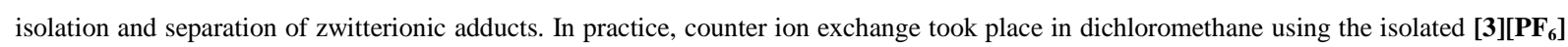
complex and racemic $\left[n-\mathrm{Bu}_{3} \mathrm{NH}\right][$ TRISPHAT-N] salt which generated, in one hour, the desired [CpRu(phen)(TRISPHAT-N)], or [CpRu(phen)(TTN)] [4] complex. Alternatively, a complete one-pot reaction could be reached in $3 \mathrm{~h}$ only by simply mixing an equimolar amounts of $\left[\mathrm{CpRu}\left(\mathrm{CH}_{3} \mathrm{CN}\right)_{3}\right]\left[\mathrm{PF}_{6}\right], 1,10$-phenanthroline and $\left[n-\mathrm{Bu}_{3} \mathrm{NH}\right][$ TRISPHAT-N] (Scheme 5). In each case, the compound was purified by column chromatography $\left(R_{\mathrm{f}} 0.98\right.$ in methylene chloride) to give a red solid in good yield $(80 \%)$. Noteworthy, when attempted, the direct anion exchange metathesis between lipophilic $\operatorname{TTN}^{-}$and $\mathrm{BAr}_{\mathrm{F}}^{-}$failed, complex [3][BAr $\mathbf{r}_{\mathrm{F}}$ ] being totally recovered at the end of the reaction. Gratifyingly, the desired air and moisture stable [4] complex was found to be moderately soluble in dichloromethane/pentane at $-20{ }^{\circ} \mathrm{C}$. X-Ray quality crystals were obtained and a structural analysis was performed (Scheme 5).

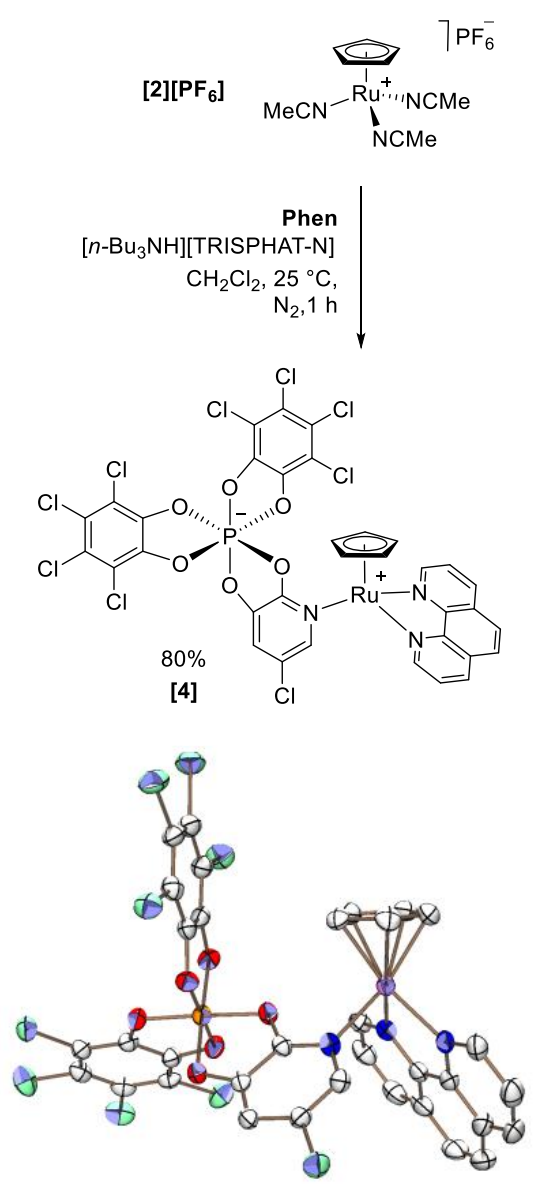

Scheme 5. Synthesis and ORTEP view of [CpRu(phen)(TTN)] [4] complex. Thermal ellipsoids are drawn at $50 \%$ probability level. Hydrogen atoms are omitted for clarity.

These X-ray structural analyses indicated that the ruthenium atom is $\pi$-coordinated to the $\mathrm{C}_{5} \mathrm{H}_{5}$ ring and in a $\sigma$ mode to $\mathrm{N}$ donor bidentate phenanthroline and to an acetonitrile fragment in a piano stool mode (Schemes 3 and 4). The average Ru-N bond length of $2.104 \AA$ for complexes [3] $\left[\mathbf{P F}_{\mathbf{6}}\right]$ and [3][BAr $\left.\mathbf{F}_{\mathbf{F}}\right]$ is in agreement with values for reported piano stool $\mathrm{CpRu}\left(\mathrm{N}^{\wedge} \mathrm{N}\right)$ complexes with, for example, an average of $\sim 2.095 \AA$ for $\left[\mathrm{CpRu}\right.$ (bipy) $\left.\left(\mathrm{CH}_{3} \mathrm{CN}\right)\right][\mathrm{OTf}] .{ }^{[35]}$ These values highlight the $\sigma$-donor character of the 1,10-Phenanthroline ligand. Similarly, the Ru-NC-Me bond length average of $2.074 \AA$ is in line with other Ru-NC-Me complexes $(2.071 \AA) .{ }^{[35,36,65,82-84]}$

The $\mathrm{Ru}-\mathrm{C}_{\mathrm{Cp}}$ distances are in the range of 2.137-2.178 $\AA$ and their average (2.153 $\AA$ ) agrees with those reported for $\left[\mathrm{CpRu}(\right.$ bipy $\left.)\left(\mathrm{CH}_{3} \mathrm{CN}\right)\right][\mathrm{OTf}]$ cationic complex. ${ }^{[35]}$ The Ru-Cp distance, in which $C p$ is the Cp centroid, for complex [PF 6 is $1.793 \AA$, and hence comparable to that of $1.791 \AA$ observed for $\mathrm{CpRu}$ (bipy) complex. Curiously, both non-coordinating [BAr ${ }_{\mathrm{F}}$ ] and coordinating anion [TTN] showed slightly shorter distances of 1.784 and 1.781 respectively. However, the symmetry breakage in [4] caused by the coordination 
of TRISPHAT-N through the ruthenium center has an effect on the $\sigma$-bond lengths as Ru-N1 (2.109 $⿱$ ) and Ru-N2 (2.088 $\AA$ ) are not equivalent anymore (Scheme 5).

As already mentioned, it has been established that the nature of anionic counterions play a crucial role in catalysis. ${ }^{[85]}$ Interactions between cationic and anionic partners can strongly affect the solubility of resulting catalysts, the rate and the selectivity of reactions or even change its course. ${ }^{[83,86-96]}$ For years it was assumed that anions such as $\mathrm{BF}_{4}^{-}, \mathrm{PF}_{6}{ }^{-}$and $\mathrm{SbF}_{6}{ }^{-}$were non-coordinating, but now there are better described as "weakly coordinating anion" (WCA) ${ }^{[97-101]}$ However, previous investigations have shown that these anions are able to interact with cations either directly or through hydrogen bonds. ${ }^{[102-106]}$ To take into account the possible occurrence of such interactions, careful analyses of hydrogen and fluorine contacts were monitored in both solid state (X-ray) and in solution (NMR ${ }^{1} \mathrm{H}^{-19} \mathrm{~F}$ HOESY experiments). In the X-ray structure packing of [3][ $\left.\mathbf{P F}_{6}\right]$, hexafluorophosphate anions were showed to interact via $\mathrm{H} \cdots \mathrm{F}$ interactions not only with the hydrogen atoms of acetonitrile ligands but also with that of the $\mathrm{Cp}$ ring $\left(\mathrm{H} \cdots \mathrm{F}<3 \AA\right.$, Table 2). The solid state structure of complex [3][BAr $\left.\mathbf{B r}_{\mathrm{F}}\right]$ was also investigated and once again, relatively short contact between fluorine atoms and both acetonitrile and Cp ligands (2.6-3.0 ̊, Table 2) could be found. Lastly, the greater distance between the (formally) positively charged ruthenium and negatively charged boron atoms in [3][BAr $\mathbf{F}]$ $(\mathrm{Ru} \cdots \mathrm{B}: 7.89 \AA$ Å) advocates in fine for a stronger Lewis acidic metal coordination site which, in retrospect, might provide higher catalyst

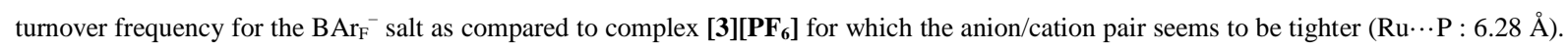
In solution, ${ }^{1} \mathrm{H}^{19}{ }^{19} \mathrm{~F}$ HOESY spectra were measured in deuterated dichloromethane for both [3][ $\left.\mathbf{P F}_{6}\right]$ and $[\mathbf{3}]\left[\mathbf{B A r}_{\mathbf{F}}\right]$ salts. In both instances, signals corresponding to NOE interactions between the anions and bound acetonitrile and $\mathrm{Cp}$ ligands could not be observed. In accordance with other studies in moderately dissociative solvents like $\mathrm{CD}_{2} \mathrm{Cl}_{2},{ }^{[83]}$ these results suggest that both $\mathrm{PF}_{6}{ }^{-}$and $\mathrm{BAr}_{\mathrm{F}}{ }^{-}$anions are not strongly paired with $[\mathrm{CpRu}]$ fragments in such solutions.

Table 2. Selected bonds lengths $[\AA]$ and angles $[\mathrm{deg}]$ for complexes [3] with estimated standard deviations in parentheses.

\begin{tabular}{|c|c|c|c|}
\hline \multirow[b]{2}{*}{$C-\mathrm{H} \cdots F$} & \multicolumn{2}{|c|}{ 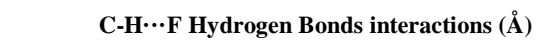 } & \multirow[b]{2}{*}{$C-\mathrm{H} \cdots F$} \\
\hline & $\mathbf{H} \cdots F$ & $C \cdots F$ & \\
\hline \multicolumn{4}{|l|}{$[3]\left[\mathrm{PF}_{6}\right]$} \\
\hline $\mathrm{C} 14-\mathrm{H} \cdots \mathrm{F} 4$ & $3.041(4)$ & $3.884(6)$ & $148.8(2)$ \\
\hline $\mathrm{C} 16-\mathrm{H}^{\cdots} \mathrm{F}$, [a] & $2.544(5)$ & $3.224(7)$ & $128.6(3)$ \\
\hline $\mathrm{NC} 19-\mathrm{H}^{\cdots} \mathrm{F}{ }^{\prime}{ }^{\text {[a] }}$ & $2.667(4)$ & $3.642(6)$ & 173.1(2) \\
\hline $\mathrm{NC} 19-\mathrm{H}^{\cdots} \mathrm{F}^{\prime}{ }^{\prime[\mathrm{a}]}$ & $2.588(4)$ & $3.366(6)$ & $136.4(3)$ \\
\hline \multicolumn{4}{|l|}{$[3]\left[\mathbf{B A} \mathbf{r}_{F}\right]$} \\
\hline $\mathrm{C} 15-\mathrm{H} \cdots \mathrm{F} 20$ & $2.614(4)$ & $3.266(6)$ & $126.2(3)$ \\
\hline $\mathrm{C} 16-\mathrm{H} \cdots \mathrm{F} 20$ & $3.051(5)$ & $3.469(7)$ & $108.3(3)$ \\
\hline NC19-H $\cdots$ F7 & $2.611(5)$ & $3.208(6)$ & $119.4(3)$ \\
\hline
\end{tabular}

[a] Fluorine atom from a symmetry equivalent molecule of $\mathrm{PF}_{6}$ in the crystal packing (') $-1+x, y, z$ and (') $1-x,-y, 1-z$.

\section{Conclusions}

In summary, the synthesis and $\mathrm{X}$-ray structural analyses of $[\mathrm{CpRu}(\mathrm{Phen})]$ fragments combined with large lipophilic $\mathrm{PF}_{6}^{-}, \mathrm{BAr}_{\mathrm{F}}^{-}$and TRISPHAT-N anions were achieved. Starting with the air-stable $\left[\mathrm{CpRu}\left(\eta^{6}\right.\right.$-naphthalene $\left.)\right]\left[\mathrm{PF}_{6}\right]$ precursor, complex $\left[\mathrm{CpRu}\left(\eta^{6}-\right.\right.$ naphthalene) $]\left[\mathrm{BAr}_{\mathrm{F}}\right]$ was prepared on multigram scale through simple ion exchange metathesis from the $\mathrm{PF}_{6}^{-}$salt. Corresponding $\left[\mathrm{CpRu}\left(\mathrm{CH}_{3} \mathrm{CN}\right)_{3}\right][\mathrm{X}]$ complexes $\left(\mathrm{X}=\mathrm{PF}_{6}, \mathrm{BAr} \mathrm{F}_{\mathrm{F}}\right)$ were generated in acetonitrile, and subsequently used for ligand exchange reaction to afford

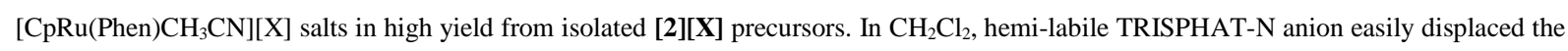
last acetonitrile ligand of derivatives [3][X] to form air stable complex [4], readily purified by chromatography. Care was also taken to study the nature of the solution and solid-state interactions occurring among combinations of $\mathrm{CpRu}$ fragments and Phen ligand on one hand, and $\mathrm{PF}_{6}^{-}, \mathrm{BAr}_{\mathrm{F}}^{-}$and TRISPHAT-N $\mathrm{N}^{-}$anions on the other. Investigations by ${ }^{1} \mathrm{H}^{-1}{ }^{19} \mathrm{~F}$ HOESY spectroscopy in solution and solid-state X-ray measurements did not indicate any significant ion pairing within both $\mathrm{PF}_{6}{ }^{-}$and $\mathrm{BAr}_{\mathrm{F}}{ }^{-}$salts. This lack of severe ion pairing constraint is in accordance with the catalytic properties of these derivatives, which allow the facile decomposition of $\alpha$-diazo- $\beta$-ketoesters and subsequent transformations of the derived metal carbenes.

\section{Experimental Section}


The dataset for this article can be found at the following DOI: 10.26037/yareta:rnzaplk6k5c7fmyb551366gope. It will be preserved for 10 years. Synthetic procedures and spectral characterization of new compounds are reported in the electronic supporting information. CCDC2026525 to 2026529 contain the supplementary crystallographic data for this work. These data can be obtained free of charge from The Cambridge Crystallographic Data Centre via www.ccdc.cam.ac.uk/data_request/cif.

\section{Acknowledgements}

We thank the University of Geneva and the Swiss National Science Foundation for financial support. We acknowledge the contributions of the Sciences Mass Spectrometry (SMS) platform at the Faculty of Sciences, University of Geneva. We also thank Júlia Viñas Lóbez, Guillaume Levitre and Romain Pertschi for proofreading the manuscript and Romain Pertschi for the addition of the accelerated procedure for the trisacetonitrile complex synthesis.

\section{Author Contribution Statement}

T. A., L. E. and C. T. performed the experiments and characterization of all materials and co-wrote the manuscript. L. G. performed the Xray diffraction studies and co-wrote sections dedicated to solid-state analyses. J. L supervised the work and wrote the manuscript. All authors commented on the manuscript.

\section{References}

[1] T. P. Gill, K. R. Mann, 'Photochemical properties of the cyclopentadienyl(.eta.6-benzene)ruthenium(II) cation. The synthesis and reactions of a synthetically useful intermediate: the cyclopentadienyltris(acetonitrile)ruthenium(II) cation', Organometallics 1982, $1,485-488$

[2] C. Slugovc, E. Rüba, R. Schmid, K. Kirchner, K. Mereiter, 'Recent Chemistry Based on the $\left[\mathrm{RuCp}\left(\mathrm{CH}_{3} \mathrm{CN}\right)_{3}\right]^{+}$Cation: Reappraisal of an Old Precursor', Monatsh. Chem. 2000, 131, 1241-1251.

[3] B. M. Trost, C. M. Older, 'A Convenient Synthetic Route to $\left[\mathrm{CpRu}\left(\mathrm{CH}_{3} \mathrm{CN}\right)_{3}\right] \mathrm{PF}_{6}$ ', Organometallics 2002, 21, 2544-2546.

[4] B. M. Trost, F. D. Toste, A. B. Pinkerton, 'Non-Metathesis Ruthenium-Catalyzed C-C Bond Formation', Chem. Rev. 2001, 101, 2067-2096.

[5] B. M. Trost, M. U. Frederiksen, M. T. Rudd, 'Ruthenium-catalyzed reactions - A treasure trove of atom-economic transformations', Angew. Chem. Int. Ed. 2005, 44, 6630-6666.

[6] C. Bruneau, P. H. Dixneuf, 'Metal vinylidenes and allenylidenes in catalysis: Applications in anti-Markovnikov additions to terminal alkynes and alkene metathesis', Angew. Chem. Int. Ed. 2006, 45, 2176-2203.

[7] D. S. Perekalin, A. R. Kudinov, 'Cyclopentadienyl ruthenium complexes with naphthalene and other polycyclic aromatic ligands', Coord. Chem. Rev. 2014, 276, 153-173.

[8] M. D. Mbaye, B. Demerseman, J. L. Renaud, L. Toupet, C. Bruneau, ' $\left[\mathrm{Cp} *\left(\eta^{2}\right.\right.$-bipy $\left.)(\mathrm{MeCN}) \mathrm{Ru}^{\mathrm{II}}\right]\left[\mathrm{PF}_{6}\right]$ catalysts for regioselective allylic substitution and characterization of dicationic $\left[\mathrm{Cp} *\left(\eta^{2}-\right.\right.$ bipy $)\left(\eta^{3}\right.$-allyl $\left.) \mathrm{RuIV}\right]\left[\mathrm{PF}_{6}\right]_{2}$ intermediates', Angew. Chem. Int. Ed. 2003, 42, 5066-5068.

[9] S. Derien, P. H. Dixneuf, 'The versatility of molecular ruthenium catalyst $\mathrm{RuCl}(\mathrm{COD})\left(\mathrm{C}_{5} \mathrm{Me}_{5}\right)$ ', J. Organomet. Chem. 2004, 689, 1382-1392.

[10] M. D. Mbaye, B. Demerseman, J. L. Renaud, L. Toupet, C. Bruneau, 'Ruthenium-catalyzed O-allylation of phenols from allylic chlorides via cationic $\mathrm{Cp}^{*}\left(\eta^{3}\right.$-allyl)(MeCN)RuX PF 6 complexes', Adv. Synth. Catal. 2004, 346, 835-841.

[11] R. Hermatschweiler, I. Fernandez, F. Breher, P. S. Pregosin, L. F. Veiros, M. J. Calhorda, 'Ruthenium-catalyzed allylic alkylation reactions: Carbonate-based catalysts and intermediates', Angew. Chem. Int. Ed. 2005, 44, 4397-4400.

[12] C. Bruneau, J.-L. Renaud, B. Demerseman, 'Pentamethylcyclopentadienyl-ruthenium catalysts for regio- and enantioselective allylation of nucleophiles', Chem. Eur. J. 2006, 12, 5178-5187.

[13] S. Mori, T. Mochida, 'Preparation and Properties of Cyclopentadienyl Ruthenocenium Complexes with 1,2-Disubstituted Benzene Ligands: Competition between Chelate Coordination and Sandwich Coordination', Organometallics 2013, 32, 283-288.

[14] K. Miyata, H. Kutsuna, S. Kawakami, M. Kitamura, 'A Chiral Bidentate sp(2)-N Ligand, Naph-diPIM: Application to CpRuCatalyzed Asymmetric Dehydrative C-, N-, and O-Allylation', Angew. Chem. Int. Ed. 2011, 50, 4649-4653.

[15] R. Uson, L. A. Oro, M. A. Ciriano, M. M. Naval, M. C. Apreda, C. Focesfoces, F. H. Cano, S. Garciablanco, 'Cyclopentadienylruthenium Complexes With Chelating Diamines And Diolefins - Crystal-Structures Of Ru(Nbd) $\left(\mathrm{PPh}_{3}\right)\left(\eta-\mathrm{C}_{5} \mathrm{H}_{5}\right)$ $\mathrm{ClO}_{4} \mathrm{And} \mathrm{Ru}\left(\left(\eta^{6}-\mathrm{C}_{6} \mathrm{H}_{5}\right) \mathrm{Ph}_{2} \mathrm{PO}\right)\left(\eta-\mathrm{C}_{5} \mathrm{H}_{5}\right) \mathrm{ClO}_{4}$ - A New Mode Of Coordination Of Triphenylphosphine Oxide', J. Organomet. Chem. 1983, 256, 331-347.

[16] R. F. N. Ashok, M. Gupta, K. S. Arulsamy, U. C. Agarwala, 'Cyclopentadienyl Ruthenium Complexes .1. Reactivity Of Some $\eta^{5}$ Cyclopentadienylbistriphenylphosphineruthenium(II) Complexes With N-Donor Heterocyclic Ligands', Inorg. Chim. Acta 1985, 98, 161-167.

[17] R. F. N. Ashok, M. Gupta, K. S. Arulsamy, U. C. Agarwala, 'Cyclopentadienyl Ruthenium Complexes .2. Reactivity Of Some $\eta^{5}$ Cyclopentadienylbis(Triphenylphosphine)-Ruthenium(II) Complexes With Nitrosyl Chloride And Nitrosyl Bromide’, Inorg. Chim. Acta 1985, 98, 169-179.

[18] R. F. N. Ashok, M. Gupta, K. S. Arulsamy, U. C. Agarwala, 'Cyclopentadienyl Ruthenium Complexes .3. Reactivity Of Some $\eta^{5}$ Cyclopentadienylbis(Triphenylphosphine)Ruthenium(II) Complexes With Nitrosyl Tribromide-2 And Dinitrogen Trioxide', Can. J. Chem. 1985, 63, 963-970.

[19] M. O. Albers, D. J. Robinson, E. Singleton, 'the chemistry of cyclopentadienyl-ruthenium and cyclopentadienyl-osmium complexes .2. novel mononuclear cyclopentadienylruthenium complexes containing aromatic amine ligands - a facile synthetic route', J. Organomet. Chem. 1986, 311, 207-215.

[20] M. O. Albers, D. C. Liles, D. J. Robinson, E. Singleton, 'The Chemistry Of Cyclopentadienyl-Ruthenium And CyclopentadienylOsmium Complexes .5. The Systematic Synthesis Of Novel Bridged Diruthenium Cations Containing Cyclopentadienyl And 
(

[dppm=bis(Diphenylphosphino)Methane - phen=phenanthroline]', Organometallics 1987, 6, 2179-2189.

[21] B. de Klerk-Engels, J. G. P. Delis, K. Vrieze, K. Goubitz, J. Fraanje, 'Synthesis Of Cyclopentadienyl-(1,4-Diisopropyl-1,3Diazabutadiene)(L)Ruthenium Trifluoromethanesulfonate $\left(\mathrm{L}=\right.$ Alkene, Alkyne, Co, Pyridine, PPh3) - X-Ray Structure Of [ $\left(\eta^{5}-\right.$ $\left.\mathrm{C}_{5} \mathrm{H}_{5}\right) \mathrm{Ru}(\mathrm{iPr}-\mathrm{DAB})\left(\eta^{2}\right.$-propene $\left.)\right]\left[\mathrm{CF}_{3} \mathrm{SO}_{3}\right]^{\prime}$, Organometallics 1994, 13, 3269-3278.

[22] B. de Klerk-Engels, J. G. P. Delis, J.-M. Ernsting, C. J. Elsevier, H.-W. Frühauf, D. J. Stufkens, K. Vrieze, K. Goubitz, J. Fraanje, 'Alkene rotation in $\left[\mathrm{Ru}\left(\eta 5-\mathrm{C}_{5} \mathrm{H}_{5}\right)(\mathrm{L} 2)\left(\eta 2\right.\right.$-alkene] $\left[\mathrm{CF}_{3} \mathrm{SO}_{3}\right]$ with $\mathrm{L} 2=\mathrm{iPr}$ - or pTol-diazabutadiene. X-ray crystal structure of $\left[\mathrm{Ru}\left(\eta 5-\mathrm{C}_{5} \mathrm{H}_{5}(\mathrm{pTol}-\mathrm{DAB})(\eta 2-\mathrm{ethene}]\left[\mathrm{CF}_{3} \mathrm{SO}_{3}\right]\right.\right.$ ', Inorg. Chim. Acta 1995, 240, 273-284.

C. Nataro, J. B. Chen, R. J. Angelici, 'Cyanide ligand basicities in $\mathrm{Cp}$ ' $\mathrm{M}(\mathrm{L})_{2} \mathrm{CN}$ complexes $(\mathrm{M}=\mathrm{Ru}, \mathrm{Fe})$. Correlation between heats of protonation and $\mathrm{CCN}^{\prime}$, Inorg. Chem. 1998, 37, 1868-1875.

[24] P. Govindaswamy, Y. A. Mozharivskyj, M. R. Kollipara, 'Synthesis and characterization of cyclopentadienylruthenium(II) complexes containing N,N '-donor Schiff base ligands: crystal and molecular structure of $\left(\eta 5-\mathrm{C}_{5} \mathrm{H}_{5}\right) \mathrm{Ru}\left(\mathrm{C}_{5} \mathrm{H}_{4} \mathrm{~N}-2-\mathrm{CH}=\mathrm{N}-\mathrm{C}_{6} \mathrm{H}_{4}-p\right.$ $\left.\left.\mathrm{OCH}_{3}\right)\left(\mathrm{PPh}_{3}\right)\right] \mathrm{PF}_{6}$ ', Polyhedron 2004, 23, 1567-1572.

[25] J. Gomez, G. Garcia-Herbosa, J. V. Cuevas, A. Arnaiz, A. Carbayo, A. Munoz, L. Falvello, P. E. Fanwick, 'Diastereospecific and diastereoselective syntheses of ruthenium(II) complexes using N,N' bidentate ligands aryl-pyridin-2-ylmethyl-amine $\mathrm{ArNH}-\mathrm{CH}_{2-}$ 2- $\mathrm{C}_{5} \mathrm{H}_{4} \mathrm{~N}$ and their oxidation to imine Ligands', Inorg. Chem. 2006, 45, 2483-2493.

[26] S. Constant, S. Tortoioli, J. Mueller, J. Lacour, 'An enantioselective CpRu-catalyzed Carroll rearrangement', Angew. Chem. Int. Ed. 2007, 46, 2082-2085.

[27] M. D. Mbaye, J.-L. Renaud, B. Demerseman, C. Bruneau, 'First enantioselective allylic etherification with phenols catalyzed by chiral ruthenium bisoxazoline complexes', Chem. Commun. 2004, 1870-1871.

[28] S. Gruber, P. S. Pregosin, 'Ruthenium Catalyzed Selective Regio-and-Mono-Allylation of Cyclic 1,3-Diketones Using Allyl Alcohols as Substrates', Adv. Synth. Catal. 2009, 351, 3235-3242.

[29] D. Linder, F. Buron, S. Constant, J. Lacour, 'Enantioselective CpRu-Catalyzed Carroll Rearrangement - Ligand and Metal Source Importance', Eur. J. Org. Chem. 2008, 5778-5785.

[30] M. Austeri, D. Linder, J. Lacour, 'Enantioselective and regioselective ruthenium-catalyzed decarboxylative etherification of allyl aryl carbonates', Chem. Eur. J. 2008, 14, 5737-5741.

[31] D. Linder, M. Austeri, J. Lacour, 'Lewis acid/CpRu dual catalysis in the enantioselective decarboxylative allylation of ketone enolates', Org. Biomol. Chem. 2009, 7, 4057-4061.

[32] M. Austeri, D. Linder, J. Lacour, '(Cyclopentadienyl)ruthenium-Catalyzed Regio- and Enantioselective Decarboxylative Allylic Etherification of Allyl Aryl and Alkyl Carbonates', Adv. Synth. Catal. 2010, 352, 3339-3347.

[33] K. Miyata, M. Kitamura, 'Asymmetric Dehydrative C-, N-, and O-Allylation Using Naph-diPIM-dioxo-i-Pr-CpRu/p-TsOH Combined Catalyst', Synthesis-Stuttgart 2012, 44, 2138-2146.

[34] M. Kitamura, K. Miyata, T. Seki, N. Vatmurge, S. Tanaka, 'CpRu-catalyzed asymmetric dehydrative allylation', Pure Appl. Chem. 2013, 85, 1121-1132.

[35] M. E. Thibault, D. V. DiMondo, M. Jennings, P. V. Abdelnur, M. N. Eberlin, M. Schlaf, 'Cyclopentadienyl and pentamethylcyclopentadienyl ruthenium complexes as catalysts for the total deoxygenation of 1,2-hexanediol and glycerol', Green Chem. 2011, 13, 357-366.

[36] D. DiMondo, M. E. Thibault, J. Britten, M. Schlaf, 'Comparison of the Catalytic Activity of $\left(\eta^{5}-\mathrm{C}_{5} \mathrm{H}_{5}\right) \mathrm{Ru}\left(2,2^{\prime}\right.$ 'bipyridine $\left.)(\mathrm{L})\right)$-Tf versus $\left(\eta^{5}-\mathrm{C}_{5} \mathrm{H}_{5}\right) \mathrm{Ru}(6,6$-diamino-2,2'bipyridine $)(\mathrm{L}) \mathrm{OTf}(\mathrm{L}=$ labile ligand) in the Hydrogenation of Cyclohexanone. Evidence for the Presence of a Metal Ligand Bifunctional Mechanism under Acidic Conditions', Organometallics 2013, 32, 6541-6554.

[37] L. Li, M. Zeng, S. B. Herzon, 'Broad-Spectrum Catalysts for the Ambient Temperature Anti-Markovnikov Hydration of Alkynes', Angew. Chem. Int. Ed. 2014, 53, 7892-7895.

[38] L. Li, S. B. Herzon, 'Temporal separation of catalytic activities allows anti-Markovnikov reductive functionalization of terminal alkynes', Nature Chem. 2014, 6, 22-27.

[39] M. Zeng, L. Li, S. B. Herzon, 'A Highly Active and Air-Stable Ruthenium Complex for the Ambient Temperature AntiMarkovnikov Reductive Hydration of Terminal Alkynes', J. Am. Chem. Soc. 2014, 136, 7058-7067.

[40] W. Baratta, A. Del Zotto, P. Rigo, 'Highly stereoselective formation of cis-enediones from $\square$-diazo carbonyl compounds catalysed by $\mathrm{RuCl}\left(\eta^{5}-\mathrm{C}_{5} \mathrm{H}_{5}\right)\left(\mathrm{PPh}_{3}\right)_{2}$, Chem. Commun. 1997, 2163-2164.

[41] W. Baratta, W. A. Herrman, R. M. Kratzer, P. Rigo, 'Half-sandwich ruthenium(II) catalysts for C-C coupling reactions between alkenes and diazo compounds', Organometallics 2000, 19, 3664-3669.

[42] G. Maas, 'Ruthenium-catalysed carbenoid cyclopropanation reactions with diazo compounds', Chem. Soc. Rev. 2004, 33, 183190.

[43] M. Basato, C. Tubaro, A. Biffis, M. Bonato, G. Buscemi, F. Lighezzolo, P. Lunardi, C. Vianini, F. Benetollo, A. Del Zotto 'Reactions of Diazo Compounds with Alkenes Catalysed by RuCl(cod)(Cp) : Effect of the Substituents in the Formation of Cyclopropanation or Metathesis Products', Chem. Eur. J. 2009, 15, 1516-1526.

[44] C. Tortoreto, T. Achard, M. Austeri, W. Zeghida, J. Lacour, 'Original Reactivity of $\square$-Diazo- $\square$-ketoesters Catalyzed by CpRu Complexes', Chimia 2014, 68, 243-247.

[45] O. A. Davis, R. A. Croft, J. A. Bull, 'Synthesis of Substituted 1,4-Dioxenes through O-H Insertion and Cyclization Using KetoDiazo Compounds', J. Org. Chem. 2016, 81, 11477-11488.

[46] J. L. Renaud, C. Bruneau, B. Demerseman, 'Ruthenium-bisimine: A new catalytic precursor for regioselective allylic alkylation', Synlett 2003, 408-410

[47] M. D. Mbaye, B. Demerseman, J.-L. Renaud, C. Bruneau, ' $\alpha$-Diimines as nitrogen ligands for ruthenium-catalyzed allylation reactions and related (pentamethylcyclopentadienyl) ruthenium complexes', J. Organomet. Chem. 2005, 690, 2149-2158.

[48] C. Tortoreto, T. Achard, W. Zeghida, M. Austeri, L. Guenee, J. Lacour, 'Enol Acetal Synthesis through Carbenoid C-H Insertion into Tetrahydrofuran Catalyzed by CpRu Complexes', Angew. Chem. Int. Ed. 2012, 51, 5847-5851.

[49] M. Austeri, D. Rix, W. Zeghida, J. Lacour, 'CpRu-Catalyzed O-H Insertion and Condensation Reactions of $\square$-Diazocarbonyl Compounds', Org. Lett. 2011, 13, 1394-1397.

[50] C. Tortoreto, T. Achard, L. Egger, L. Guenee, J. Lacour, 'Synthesis of Spiro Ketals, Orthoesters, and Orthocarbonates by CpRuCatalyzed Decomposition of $\square$-Diazo- $\square$-ketoesters', Org. Lett. 2016, 18, 240-243.

[51] T. Achard, C. Tortoreto, A. I. Poblador-Bahamonde, L. Guenee, T. Burgi, J. Lacour, 'CpRu -Catalyzed Carbene Insertions into Epoxides: 1,4-Dioxene Synthesis through SN 1-Like Chemistry with Retention of Configuration', Angew. Chem. Int. Ed. 2014, 53, 6140-6144.

[52] L. Egger, L. Guenee, T. Burgi, J. Lacour, 'Regioselective and Enantiospecific Synthesis of Dioxepines by (Cyclopentadienyl) ruthenium-Catalyzed Condensations of Diazocarbonyls and Oxetanes', Adv. Synth. Catal. 2017, 359, 2918-2923.

[53] A. Pfaltz, J. Blankenstein, R. Hilgraf, E. Hormann, S. McIntyre, F. Menges, M. Schonleber, S. P. Smidt, B. Wustenberg, N. Zimmermann, 'Iridium-catalyzed enantioselective hydrogenation of olefins', Adv. Synth. Catal. 2003, 345, 33-43. 
S. P. Smidt, N. Zimmermann, M. Studer, A. Pfaltz, 'Enantioselective hydrogenation of alkenes with iridium-PHOX catalysts: A kinetic study of anion effects', Chem. Eur. J. 2004, 10, 4685-4693.

[55] S. J. Roseblade, A. Pfaltz, 'Iridium-Catalyzed Asymmetric Hydrogenation of Olefins', Acc. Chem. Res. 2007, 40, 1402-1411.

[56] E. P. Kündig, F. R. Monnier, 'Efficient synthesis of tris(acetonitrile)-( $\eta^{5}$-cyclopentadienyl)ruthenium(II) hexafluorophosphate via ruthenocene', Adv. Synth. Catal. 2004, 346, 901-904.

[57] E. Bocekova-Gajdošíkova, B. Epik, J. Chou, K. Akiyama, N. Fukui, L. Guénée, E. P. Kündig, 'Microwave-Assisted Synthesis and Transformations of Cationic $\mathrm{CpRu}(\mathrm{II})$ (naphthalene) and $\mathrm{CpRu}(\mathrm{II})$ (naphthoquinone) Complexes', Helv. Chim. Acta 2019, 102, e1900076.

[58] E. E. Karslyan, D. S. Perekalin, P. V. Petrovskii, K. A. Lyssenko, A. R. Kudinov, 'Thermal arene exchange in the naphthalene complex $\mathrm{CpRu}\left(\eta^{6}-\mathrm{C}_{10} \mathrm{H}_{8}\right)^{+}$, Russ. Chem. Bull. 2008, 57, 2201-2203.

[59] L. Hintermann, L. Xiao, A. 1. Labonne, U. Englert, '[CpRu(n6-naphthalene)]PF6 as Precursor in Complex Synthesis and Catalysis with the Cyclopentadienyl-Ruthenium(II) Cation', Organometallics 2009, 28, 5739-5748.

[60] F. Grepioni, G. Cojazzi, D. Braga, E. Marseglia, L. Scaccianoce, B. F. G. Johnson, 'Crystal architecture of the cocrystalline salt $\mathrm{Ru}\left(\eta^{5}-\mathrm{C}_{5} \mathrm{H}_{5}\right)\left(\eta^{6}\right.$-trans- $\left.\mathrm{PhCH}=\mathrm{CHPh}\right) \mathrm{PF}_{6}$ center dot 0.5 trans- $\mathrm{PhCH}=\mathrm{CHPh}$ and the reversible order-disorder phase transition in $\mathrm{Ru}\left(\eta^{5}-\mathrm{C}_{5} \mathrm{H}_{5}\right)\left(\eta^{6}-\mathrm{C}_{6} \mathrm{H}_{6}\right) \mathrm{PF}_{6}$ ', J. Chem. Soc., Dalton Trans. 1999, 553-558.

[61] D. S. Perekalin, E. E. Karslyan, P. V. Petrovskii, A. O. Borissova, K. A. Lyssenko, A. R. Kudinov, 'Arene Exchange in the Ruthenium-Naphthalene Complex $\mathrm{CpRu}\left(\mathrm{C}_{10} \mathrm{H}_{8}\right)^{+}$, Eur. J. Inorg. Chem. 2012, 1485-1492.

[62] A. Mercier, W. C. Yeo, J. Y. Chou, P. D. Chaudhuri, G. Bernardinelli, E. P. Kündig, 'Synthesis of highly enantiomerically enriched planar chiral ruthenium complexes via Pd-catalysed asymmetric hydrogenolysis', Chem. Commun. 2009, 5227-5229.

[63] Recently, an accelerated procedure was developed. Please see the Supporting Information for Procedure 2 on page S4.

[64] D. B. Grotjahn, H. C. Lo, 'Ruthenium alkoxycarbene complexes from an acetal function by C-O bond cleavage and alcohol elimination', Organometallics 1996, 15, 2860-2862.

[65] E. Ruba, W. Simanko, K. Mauthner, K. M. Soldouzi, C. Slugovc, K. Mereiter, R. Schmid, K. Kirchner, ${ }^{' R u C p}\left(\mathrm{PR}_{3}\right)\left(\mathrm{CH}_{3} \mathrm{CN}\right)_{2}$ $\mathrm{PF}_{6}(\mathrm{R}=\mathrm{Ph}, \mathrm{Me}, \mathrm{Cy})$. Convenient precursors for mixed ruthenium(II) and ruthenium(IV) half-sandwich complexes', Organometallics 1999, 18, 3843-3850.

[66] C. M. Standfest-Hauser, K. Mereiter, R. Schmid, K. Kirchner, 'Formation of ruthenium-aminocarbene complexes from aldimines and aminals', Eur. J. Inorg. Chem. 2003, 1883-1892.

[67] N. Kumagai, S. Matsunaga, M. Shibasaki, 'Cooperative catalysis of a cationic ruthenium complex, amine base, and Na salt: Catalytic activation of acetonitrile as a nucleophile', J. Am. Chem. Soc. 2004, 126, 13632-13633.

[68] N. Kumagai, S. Matsunaga, M. Shibasaki, 'Catalytic chemoselective addition of acetonitrile to enolizable aldehydes with cationic Ru complex/DBU combination', Chem. Commun. 2005, 3600-3602.

[69] D. B. Grotjahn, C. R. Larsen, J. L. Gustafson, R. Nair, A. Sharma, 'Extensive Isomerization of Alkenes Using a Bifunctional Catalyst: An Alkene Zipper', J. Am. Chem. Soc. 2007, 129, 9592-9593.

[70] N. Kumagai, S. Matsunaga, M. Shibasaki, 'Catalytic nucleophilic activation of acetonitrile via a cooperative catalysis of cationic Ru complex, DBU, and NaPF6', Tetrahedron 2007, 63, 8598-8608.

[71] A. L. Osipov, D. V. Gutsulyak, L. G. Kuzmina, J. A. K. Howard, D. A. Lemenovskii, G. Suess-Fink, G. I. Nikonov, 'Halfsandwich trihydrido ruthenium complexes', J. Organomet. Chem. 2007, 692, 5081-5085.

[72] H. L. Ji, J. H. Nelson, A. Decian, J. Fischer, L. Solujic, E. B. Milosavljevic, 'Synthesis, Characterization, And Reaction Chemistry Of Chiral Half-Sandwich Ruthenium Phosphaallyl Complexes', Organometallics 1992, 11, 401-411.

[73] C. M. Standfest-Hauser, T. Lummerstorfer, R. Schmid, K. Kirchner, H. Hoffmann, M. Puchberger, 'Immobilization, characterization, and preliminary reactivity studies of halfsandwich ruthenium complexes on silica', Monatsh. Chem. 2003, 134, 1167-1175.

[74] S. Bolano, L. Gonsalvi, F. Zanobini, F. Vizza, V. Bertolasi, A. Romerosa, M. Peruzzini, 'Water soluble ruthenium cyclopentadienyl and aminocyclopentadienyl PTA complexes as catalysts for selective hydrogenation of $\square, \square$-unsaturated substrates (PTA=1,3,5-triaza-7-phosphaadamantane)', J. Mol. Catal. 2004, 224, 61-70.

[75] C. A. Mebi, B. J. Frost, 'Effect of $\mathrm{pH}$ on the biphasic catalytic hydrogenation of benzylidene acetone using $\mathrm{CpRu}(\mathrm{PTA})_{2} \mathrm{H}^{\prime}$, Organometallics 2005, 24, 2339-2346.

[76] C. Slugovc, W. Simanko, K. Mereiter, R. Schmid, K. Kirchner, 'Thermodynamically controlled formation of diastereopure threelegged piano-stool complexes. The substitution chemistry of $\mathrm{RuCp}$ (aminophosphinoferrocene) $\left(\mathrm{CH}_{3} \mathrm{CN}\right) \mathrm{PF}_{6}$ ', Organometallics 1999, 18, 3865-3872.

[77] F. Chevallier, B. Breit, 'Self-assembled bidentate ligands for Ru-catalyzed anti-Markovnikov hydration of terminal alkynes', Angew. Chem. Int. Ed. 2006, 45, 1599-1602.

[78] In practice, 2 hours are necessary for complex [2][ $\left.\mathrm{PF}_{6}\right]$ and 4 hours for $[2]\left[\mathrm{BAr}_{\mathrm{F}}\right]$ respectively.

[79] The naphthalene ligand must be washed away from the reaction medium by addition of hexane and then removal of the surnactant.

[80] S. Constant, R. Frantz, J. Müller, G. Bernardinelli, J. Lacour, 'TRISPHAT-N: A Chiral Hexacoordinated Phosphate Anion with Unique Asymmetric Coordinating Properties', Organometallics 2007, 26, 2141-2143.

[81] S. Constant, S. Tortoioli, J. Mueller, D. Linder, F. Buron, J. Lacour, 'Air- and microwave-stable $\left(\mathrm{C}_{5} \mathrm{H}_{5}\right) \mathrm{Ru}$ catalysts for improved regio and enantioselective carroll rearrangements', Angew. Chem. Int. Ed. 2007, 46, 8979-8982.

[82] O. Y. Carreon, M. A. Leyva, J. M. FernandezG, A. Penicaud, '(Acetonitrile-N) $\left(\eta^{5}\right.$-cyclopentadienyl)bis(triphenylphosphineP)ruthenium(II) tetrafluoroborate', Acta Crystallographica Section C-Crystal Structure Communications 1997, 53, 301-302.

[83] P. G. A. Kumar, P. S. Pregosin, M. Vallet, G. Bernardinelli, R. F. Jazzar, F. Viton, E. P. Kündig, 'Toward an understanding of the anion effect in CpRu-based Diels-Alder catalysts via PGSE-NMR measurements', Organometallics 2004, 23, 5410-5418.

[84] F. Boeck, T. Kribber, L. Xiao, L. Hintermann, 'Mixed Phosphane $\eta^{5}-\mathrm{CpRuCl}\left(\mathrm{PR}_{3}\right)_{2}$ Complexes as Ambifunctional Catalysts for Anti-Markovnikov Hydration of Terminal Alkynes', J. Am. Chem. Soc. 2011, 133, 8138-8141.

[85] A. Macchioni, 'Ion pairing in transition-metal organometallic chemistry', Chem. Rev. 2005, 105, 2039-2073.

[86] D. A. Evans, J. A. Murry, P. Vonmatt, R. D. Norcross, S. J. Miller, ' $C_{2}$-Symmetric Cationic Copper(II) Complexes As Chiral Lewis-Acids - Counterion Effects In The Enantioselective Diels-Alder Reaction', Angew. Chem. Int. Ed. 1995, 34, 798-800.

[87] A. Macchioni, G. Bellachioma, G. Cardaci, V. Gramlich, H. Ruegger, S. Terenzi, L. M. Venanzi, 'Cationic bis- and tris $\left(\eta^{2}-\right.$ (pyrazol-1-yl)methane) acetyl complexes of Iron(II) and Ruthenium(II): Synthesis, characterization, reactivity, and interionic solution structure by NOESY NMR spectroscopy', Organometallics 1997, 16, 2139-2145.

[88] A. Macchioni, G. Bellachioma, G. Cardaci, M. Travaglia, C. Zuccaccia, B. Milani, G. Corso, E. Zangrando, G. Mestroni, C. Carfagna, M. Formica, 'Counterion effect on $\mathrm{CO} /$ styrene copolymerization catalyzed by cationic palladium(II) organometallic complexes: An interionic structural and dynamic investigation based on NMR spectroscopy', Organometallics 1999, 18, 30613069 .

[89] A. Macchioni, C. Zuccaccia, E. Clot, K. Gruet, R. H. Crabtree, 'Selective ion pairing in [Ir(bipy) $\left.\mathrm{H}_{2}\left(\mathrm{PRPh}_{2}\right)_{2}\right] \mathrm{A}\left(\mathrm{A}=\mathrm{PF}_{6}, \mathrm{BF}_{4}\right.$, $\mathrm{CF}_{3} \mathrm{SO}_{3}, \mathrm{BPh}_{4}, \mathrm{R}=\mathrm{Me}, \mathrm{ph}$ ): Experimental identification and theoretical understanding', Organometallics 2001, 20, 2367-2373. 
[90] C. Zuccaccia, G. Bellachioma, G. Cardaci, A. Macchioni, 'Solution structure investigation of Ru(II) complex ion pairs: Quantitative NOE measurements and determination of average interionic distances', J. Am. Chem. Soc. 2001, 123, 11020-11028.

[91] D. B. Llewellyn, D. Adamson, B. A. Arndtsen, 'A novel example of chiral counteranion induced enantioselective metal catalysis : The importance of ion-pairing in copper-catalyzed olefin aziridination and cyclopropanation', Org. Lett. 2000, 2, 4165-4168.

[92] J. R. Miecznikowski, S. Grundemann, M. Albrecht, C. Megret, E. Clot, J. W. Faller, O. Eisenstein, R. H. Crabtree, 'Outer sphere anion participation can modify the mechanism for conformer interconversion in Pd pincer complexes', Dalton Trans. 2003, 831838

[93] M. G. Basallote, M. Besora, J. Duran, M. J. Fernandez-Trujillo, A. Lledos, M. A. Manez, F. Maseras, 'The effect of the "inert" counteranions in the deprotonation of the dihydrogen complex trans- $\left[\mathrm{FeH}\left(\eta^{2}-\mathrm{H}_{2}\right)(\mathrm{dppe})_{2}\right]^{+}$: Kinetic and theoretical studies', J. Am. Chem. Soc. 2004, 126, 2320-2321.

[94] M. Ludwig, S. Stromberg, M. Svensson, B. Akermark, 'An exploratory study of regiocontrol in the Heck type reaction. Influence of solvent polarity and bisphosphine ligands', Organometallics 1999, 18, 970-975.

[95] A. Rifat, N. J. Patmore, M. F. Mahon, A. S. Weller, 'Rhodium phosphines partnered with the carborane monoanions $\mathrm{CB}_{11} \mathrm{H}_{6} \mathrm{Y}_{6}(-)$ ( $\mathrm{Y}=\mathrm{H}, \mathrm{Br})$. Synthesis and evaluation as alkene hydrogenation catalysts', Organometallics 2002, 21, 2856-2865.

[96] N. Takenaka, Y. Huang, V. H. Rawal, 'The first catalytic enantioselective Diels-Alder reactions of 1,2-dihydropyridine: efficient syntheses of optically active 2-azabicyclo 2.2.2 octanes with chiral BINAM derived Cr(III) salen complexes', Tetrahedron 2002, 58, 8299-8305.

[97] T. Wititsuwannakul, M. B. Hall, J. A. Gladysz, 'A computational study of hydrogen bonding motifs in halide, tetrafluoroborate, hexafluorophosphate, and tetraarylborate salts of chiral cationic ruthenium and cobalt guanidinobenzimidazole hydrogen bond donor catalysts; acceptor properties of the "BArf" anion', Polyhedron 2020, 187, 114618.

[98] A. R. Wegener, C. Q. Kabes, J. A. Gladysz, 'Launching Werner Complexes into the Modern Era of Catalytic Enantioselective Organic Synthesis', Acc. Chem. Res. 2020.

[99] A. Bihlmeier, M. Gonsior, I. Raabe, N. Trapp, I. Krossing, 'From Weakly Coordinating to Non-Coordinating Anions? A Simple Preparation of the Silver Salt of the Least Coordinating Anion and Its Application To Determine the Ground State Structure of the $\operatorname{Ag}(\eta 2-\mathrm{P} 4)^{2+}$ Cation', Chem. Eur. J. 2004, 10, 5041-5051.

[100] R. V. Honeychuck, W. H. Hersh, 'Coordination of "noncoordinating" anions: synthesis, characterization, and x-ray crystal structures of fluorine-bridged hexafluoroantimonate(1-), tetrafluoroborate(1-), and hexafluorophosphate(1-) adducts of $\left[\mathrm{R}_{3} \mathrm{P}(\mathrm{CO})_{3}(\mathrm{NO}) \mathrm{W}\right]+$. An unconventional order of anion donor strength', Inorg. Chem. 1989, 28, 2869-2886.

[101] S. H. Strauss, 'The search for larger and more weakly coordinating anions', Chem. Rev. 1993, 93, 927-942.

[102] R. Romeo, N. Nastasi, L. M. Scolaro, M. R. Plutino, S. Albinati, A. Macchioni, 'Molecular structure, acidic properties, and kinetic behavior of the cationic complex (methyl)(dimethyl sulfoxide)(bis-2-pyridylamine)platinum(II) ion', Inorg. Chem. 1998, $37,5460-5466$.

[103] J. S. Song, D. J. Szalda, R. M. Bullock, 'Alcohol complexes of tungsten prepared by ionic hydrogenations of ketones', Organometallics 2001, 20, 3337-3346.

[104] L. G. Alves, G. Dazinger, L. F. Veiros, K. Kirchner, 'Unusual Anion Effects in the Iron-Catalyzed Formation of 3 Hydroxyacrylates from Aromatic Aldehydes and Ethyl Diazoacetate', Eur. J. Inorg. Chem. 2010, 3160-3166.

[105] A. Moreno, P. S. Pregosin, L. F. Veiros, A. Albinati, S. Rizzato, 'PGSE NMR diffusion Overhauser studies on Ru(Cp*)( $\eta^{6}$-arene) $\mathrm{PF}_{6}$, plus a variety of transition-metal, inorganic, and organic salts: An overview of ion pairing in dichloromethane', Chem. Eur. J. 2008, 14, 5617-5629.

[106] P. S. Pregosin, 'NMR spectroscopy and ion pairing: Measuring and understanding how ions interact', Pure Appl. Chem. 2009, 81, 615-633. 